\title{
KEBIJAKAN KEIMIGRASIAN DI MASA PANDEMI \\ COVID-19
}

\author{
Irwan Safri ${ }^{1}$, Anggisa Ayu Elmin ${ }^{2}$, Suci Lestari ${ }^{3}$ \\ ${ }^{1}$ Sekolah Tinggi IImu Hukum Amsir, Pare - pare, Irwansafri7@gmail.com \\ ${ }^{2}$ Sekolah Tinggi Ilmu Hukum Amsir, Pare - pare, anggisaayuelmn98@gmail.com \\ ${ }^{3}$ Sekolah Tinggi Ilmu Hukum Amsir, Pare - pare, sucisakti@yahoo.com
}

\section{ABSTRACT}

Covid Disease 2019 (Covid-19) showed up toward the finish of 2019 in Wuhan, Hubei Province, China. The infection spread to different nations, including Indonesia. To forestall Covid-19 from spreading in Indonesia, the public authority, through the Directorate General of Immigration, given a few approaches while as yet maintaining basic freedoms. This examination will answer two issues. First is the means by which far types of movement strategy identified with Covid-19 from the viewpoint of basic liberties, second what are the deterrents confronted while executing the approach. The examination strategy utilized is subjective and with deductive reasoning rationale. This examination infers that the public authority sets two approaches during Covid-19. They are limitations for outsiders to Indonesian region and identification administrations limitations. On a basic level, the two approaches don't contain components of common liberties infringement. Other than of that, there is no critical obstruction during the time spent carrying out the approach so everything went on while as yet maintaining basic freedoms.

Keywords: covid-19; policy; immigration; human rights. 


\section{PENDAHULUAN}

Seperti kita ketahui bersama, Coronavirus Disease 2019 atau yang lebih dikenal dengan virus Covid-19 muncul di Wuhan, ibu kota Provinsi Hubei, China pada akhir tahun 2019 lalu. Dalam waktu singkat, virus tersebut menyebar keberbagai negara di Asia, seperti Korea Selatan, Hongkong, Taiwan, Malaysia, Singapura, Indonesia, Iran, dll. Tak hanya di Asia, ternyata virus Covid-19 perlahan merambah ke Eropa, Australia bahkan hingga benua Amerika Serikat.

Di Indonesia sendiri, Presiden Jokowi dan Menteri Kesehatan pertama kali mengumumkan kasus positif Covid-19 pada 2 Maret 2020. Dimulai dengan dua kasus positif di Kota Depok, Jawa Barat, jumlah korban berlipat ganda dengan cepat dan terus berlanjut. Tersebarke 34 provinsi di Indonesia. Per 11 Mei 2020, jumlah orang yang dinyatakanpositif Covid-19 di Indonesia adalah 14.265 orang, jumlah orang yang sembuh 2.881 orang, dan jumlahkematian 991 orang.

Pada tahun 2019 Pemerintah Indonesia belum memiliki kebijakan global yang efektif untuk menekan penyebaran wabah Covid-19, malah lebih memilih menerapka nkebijakan social distancing dan mengurangi mobilitas orang dari satu tempat ketempa tlain. Dalam mengurangi mobilitas ini, pemerintah memainkan peran yang sangat penting melalui keimigrasian. Hal ini sejalan dengan pengertian keimigrasian, yaitu perdagangan manusia yang masuk atau keluar wilayah Indonesia dan pengawasannya dalam rangka pengamanan kedaulatan negara.

Untuk tetap menjaga goyangan negara, badan public dapat membuat strategi yang diidentikkan dengan lalulintas perseorangan dan pengelolaan pihakluar di Indonesia. Memang, otoritas public melalui imigrasi dapat menolak orang luar untuk memasuki wilayah Indonesia jika individu tersebut mengalami penyakit yang tidak dapat ditahan yang membahayakan kesejahteraan umum, untuk situasi Covid-19 ini. Meskipun memiliki kekuatan ini, migrasi tetap harus melakukan pendekatannya dengan tetap memperhatikan dan mempertahankan HAM.

Sehubungan dengan hal tersebut, Jurnal ini akan mengkaji sejauh mana jenis strategi pergerakan yang diidentifikasi dengan Covid-19 dilihat dari sudut pandang HAM dan hambatan apa yang dihadapi saat melakukan pendekatan ini. 


\section{METODE PENELITIAN}

Metode penelitian ini menggunakan penelitian normatif, yakni Penelitian Hukum Normatif merupakan penelitian hukum yang dilakukan dengan cara meneliti bahan pustaka atau data sekunder. Penelitian hukum normatif disebut juga penelitian hukum doctrinal Penelitian yang dilakukan bersifat deskriptif analitis yaitu menggambarkan,menganilisis, menyimpulkan masalah-masalah yang menjadi objek penelitian. (Syahruddin Nawi, 2017: 9)

\section{PEMBAHASAN DAN ANALISIS}

\section{A. Konsep Hak Asasi Manusia dalam Perspektif Keimigrasian}

Sesuai Undang-Undang Nomor 39 Tahun 1999 tentang Hak Asasi Manusia, HAM adalah sekumpulan hak intrinsic dalam kodrat dan keberadaan manusia sebagai makhluk Tuhan Yang Maha Esa dan merupakananugerah-Nya yang harus dijunjung, dipertahankan dan dijamin oleh negara, hukum, pemerintah, dan semua orang untuk kehormatan dan jaminan ketenanga nmanusia. UDHR 1948 menegaskan bahwa "semua individu yang dikandung bebas dan memiliki rasa hormat dan hak yang sama. Mereka sebagai manusia telah berbakat dengan akal dan hati dan keinginan untuk mengenal satu sama lain, untuk terhubung satu sama lain dalam perasaan persaudaraan.

Pemahaman tentang HAM tidak hanya dirasakan di Indonesia tetapi juga dirasakan secara luas. Berbagai negara juga telah melakukan perjalanan panjang untuk mempertahankan HAM untuk mencapai kehidupan megah yang dibebaskan dari ekspansionisme, penaklukan dan siksaan. Salah satu pencapaian dari upaya ini adalah penerimaan Deklarasi Universal Hak Asasi Manusia oleh Perserikatan Bangsa-Bangsa pada tahun 1948. Oleh karena itu, semua bangsa di planet ini secara etis diperlukan untuk menghormati, mempertahankan dan menjamin HAM.

Cara untuk membatasi HAM tidak dapat diselesaikan secara konsekuen, namun harus melalui system tertentu. Hal ini tertuang dalam Undang-Undang Dasar Negara Republik Indonesia Tahun 1945 pasal 28J ayat 2 yang berbunyi, "Dalam menjalankan hak dan kebebasannya, setiap orang wajib tunduk kepada pembatasan yang ditetapkan dengan undang-undang dengan maksud semata-mata untuk menjamin pengakuan 
serta penghormatan atas hak dan kebebasan orang lain dan untuk memenuhi tuntutan yang adil sesuai dengan pertimbangan moral, nilai-nilai agama, keamanan, dan ketertiban umum dalam suatu masyarakat demokratis.

Pandemi Covid-19 merupakan bencana yang mendunia, sehingga Pemerintah Indonesia akhirnya bereaksi dengan menyatakannya sebagai krisis kesejahteraan hanya sebagai peristiwa publik non-bencana. Kepastian status krisis kesejahteraan diatur secara sah dalam Peraturan Presiden Nomor 11 Tahun 2020 tentang Penetapan Keadaan Darurat Kesehatan Masyarakat Untuk Penyakit Virus Corona 2019 (Covid-19) dan Peraturan Presiden Nomor 12 Tahun 2020 tentang Penetapan Status Bencana Non-alam secara Nasional. Dalam keadaan krisis ini, Pemerintah dapat mengurangi atau membatasi HAM tertentu. Batasan semacam itu harus bersifat sementara, diusulkan untuk mengatasi keadaan darurat dan tidak boleh terlalu menonjokan diri.

Sebagai negara yang menjaga HAM, Pemerintah Indonesia berkewajiban memberikan kepastian hukum kepada warganya di dalam dan di luar negeri, sama seperti warga asing di Indonesia. Terkait keadaan Covid-19, pakar imigrasi dapat menolak orang luar untuk masuk ke wilayah Indonesia jika diduga pihak luar tersebut sedang mengalami penyakit yang tidak dapat ditahan, misalnya Covid-19 yang dapat membahayakan kesehatan secara umum.

Untuk memperluas kerjasama gerakan dengan tujuan akhir untuk menghormati dan menjaga HAM, setidaknya ada empat elemen migrasi yang disampaikannya, yaitu penyelenggara gerakan khusus, persyaratan hukum, keamanan negara, dan bekerja dengan peningkatan bantuan human government.

Berikut ini akan menggambarkan empat kapasitas yaitu Pertama - tama, administrasi imigrasi. Administrasi publik, untuk situasi ini administrasi imigrasi, adalah upaya negara untuk memuaskan hak warga atas produk. Administrasi tersebut dapat berupa administrasi perizinan rumah bagi orang luar, penerbitan visa bagi penduduk Indonesia, bahkan administrasi data tentang imigrasi melalui komunitas panggilan atau media berbasis web.

Sebagai bentuk kewajiban penyelenggaraan pemerintahan public berbasis HAM, Kementerian Hukum dan HAM memberikan Permenkumham RI Nomor 27 Tahun 2018 tentang Penghargaan Pelayanan Publik Berbasis Hak Asasi Manusia. 
Imigrasi sebagai organisasi negara yang memiliki kedudukan sebagai pelaksana hukum pergerakan untuk menjamin kepastian dan kepastian legitimasi wilayah setempat. Pelaksanaan otorisasi hukum pergerakan tersebut tertuang dalam Undang-Undang Nomor 6 Tahun 2011 tentang Migrasi Twoly, secaraspesifik:

1. Tindakan Administratif Migrasi (Bab VII, dimulaidari Pasal 75-80)

2. Tindak Pidana Migrasi dalam interaksi pengadilan (Bab XI, terdiridari 23 Pasal 113-136). Pelanggaran pelanggaran diarahkan pada Pasal 116, 117,120b, dan 133e. Kemudian, tindak pidana yang diatur dalam pasal 113-116 dikurangi menjadi pelanggaran.

Tindakan Administrasi Migrasi adalah kewenangan Pejabat Imigrasi yang diberikan kepada pihak luar di wilayah Indonesia yang dianggap telah mengajukan demonstrasi berbahaya yang justru dapat mengganggu permintaan publik. Kegiatan berbahaya tersebut, misalnya, dengan menyelesaikan publisitas yang disengaja atau melakukan kegiatan berbau SARA untuk membagi negara.

Soal pelanggaran migrasi menjadi kewenangan Penyidik Pegawai Negeri Sipil (PPNS). PPNS menyelesaikan serangkaian latihan mulai dari menerima laporan, mencari bukti, mengarahkan penilaian, hingga menyerahkan dokumen perkara kepada penyidik publik. Jenis pelanggaran yang biasa dilakukan oleh penduduk Indonesia yang masuk dan keluar tanpa melalui TPI, memberikan jaminan kepada pihak luar yang salah, menjadi penolong yang diciptakan, berpartisipasi dalam eksploitasi ilegal, dan memberikan informasi yang salah saat mengajukan permohonan identifikasi.

Jenis pelanggaran yang umumnya dilakukan oleh pihak luar antara lain penganiayaan atas hibah rumah, pemanfaatan pendukung khayalan, tidak mengumumkan bila ada penyesuaian status atau alamat tempat tinggal, masuk menggunakan catatan palsu, mendistorsi karakter saat mengajukan identitas Indonesia, dan terlibat dengan eksploitasi ilegal. Dengan disposisi tegas dari pergerakan ini, diyakini tidak akan adalagi penduduk Indonesia dan pihak luar yang melakukan pelanggaran di daerah migrasi sehingga setiap penduduk Indonesia dan orang luar di Indonesia dipastikan memiliki pilihan untuk memiliki rasa aman dan aman dalam menyelesaikan latihan mereka. 
Keamanan negara saat ini merupakan isu yang sangat panas karena periode globalisasi. Pelanggaran, misalnya, organisasi penyelenggara narkoba, eksploitasi ilegal, penghinaan, penggelapan pajak dapat berpotensi membahayakan keamanan negara. Untuk situasi ini, spesialis gerakan memiliki kekuatan penuh untuk mencegah orang Indonesia yang berisiko meninggalkan negara hanya untuk menghindari orang luar yang mungkin dapat mengganggu keselamatan publik.

Terlebih lagi, para ahli pergerakan juga melakukan pengawasan penuh terhadap warga Indonesia dan pihak luar. Bagi penduduk Indonesia, pengendalian pergerakan dapat dimulai saat mengajukan visa, selanjutnya saat keluar dan masuk domain Indonesia, dalam hal apapun, ketika penduduk Indonesia berada di luar wilayah Indonesia. Sementara bagi pihak luar, pergerakan informasi mengamati dimulai pada saat pengajuan visa, saat masuk dan keluar Indonesia, saat pemberian rumah, dan mengingat itu adalah domain Indonesia.

Fasilitator pembinaan pemerintah kelompok masyarakat. Untukmembantu program pemerintah untuk pendampingan perorangan dari pemerintah, migrasi telah memberikan beberapa strategi, khususnya di bidang ekonomi dan industry perjalanan. Pendekatan migrasi bagi penduduk Indonesia dapat melalui proses untuk meningkatkan administrasi laporan perjalanan. Bagi pihak luar, dengan melaksanakan strategi Free Visit Visa (BVK), Visit Visa on Arrival (VKSK), Visa on Arrival (VoA), dan penyempurnaan metodologi home grant.

\section{B.Kebijakan Keimigrasian di Masa Pandemi Covid-19 dalam Perspektif HAM}

Sejak isu Covid-19 di kota Wuhan, Provinsi Hubei, China menjelang akhir tahun 2019 lalu, Pemerintah terus mencermati perkembangan penularannya agar tidak masuk ke wilayah Indonesia. Untuk mencegah masuknya Covid-19, pemerintah memberikan strategi yang berbeda, terutama di wilayah migrasi, yang memiliki kewenangan untuk melakukan kerangka strategi tertentu terhadap pihak luar dengan tetap menjaga HAM. Tak hanyaitu, otoritas publik juga memberikan beberapa pengaturan di bidang pergerakan ketika Covid-19 mulaimenyebar di wilayah Indonesia. Berikut adalah klarifikasi lebih lanjut dari strategi tersebut.

\section{Strategi Pembatasan Warga Negara Asing di Wilayah Indonesia}


Mungkin tidak ada seorang pun yang merasa bahwa awal tahun 2020 akan tercatat sebagai tahun kedua yang luar biasa bagi sebagian besar dari total populasi. Secara mengejutkan, infeksi Covid-19 menyebar dengan cepat mulai dari satu negara lalu ke negara berikutnya. Untuk memperkirakan penyebarannya di Indonesia, otoritas public telah memberikan beberapa pengaturan, terutama yang diidentifikasi dengan pihak luar, mengingat sumber penularannya berasal dari luar negeri.

Strategi gerakan utama yang diambil oleh badan publik yang diidentikkan dengan penanggulangan Covid-19 adalah dengan memberikan Peraturan Menteri Hukum dan Hak Asasi Manusia Republik Indonesia Nomor 3 Tahun 2020 tentang Penghentian Sementara Visa Kunjungan, Visa, dan Pemberian Izin Tinggal Paksa. untuk Warga Negara Republik Rakyat Tiongkok. Pendekatan tersebut diberikan dimulai pada tanggal 5 Februari 2020 dengan tujuan untuk menghentikan sebentar pemberian Visa Kunjungan Gratis (BVK) dan visa bagi orang luar Republik Rakyat Tiongkok seperti halnya orang luar yang memiliki latar belakang ditandai dengan perpindahan ke Republik Rakyat Tiongkok dalam waktu 14 ( empat belas) hari sebelum masuk wilayah Indonesia. Mengenai orang luar Republik Rakyat China yang sudah efektif berada di Indonesia dan tidak bisa kembali ke negaranya karena kekurangan sarana transportasi, maka otoritas public telah memberikan Izin Tinggal Paksa (ITKT). Peraturan Hak Asasi Manusia Nomor 7 Tahun 2020 tentang Pemberian Visa dan Izin Tinggal dalam Upaya Pencegahan Masuknya Virus Corona.

Pengajuan visa kepada Pejabat Dinas Luar Negeri di Perwakilan Republik Indonesia di Republik Rakyat Tiongkok dapat diajukan dengan syarat membawa surat bebas Covid-19 dari ahli kesejahteraan lingkungan dalam bahasa Inggris, telah 14 (empat belas) hari di wilayah tanpa covid di Republik Rakyat Cina. 19, dan akan diisolasi selama 14 (empat belas) hari oleh Pemerintah Republik Indonesia atau singgah / perjalanan selama 14 (empat belas) hari di berbagai negara yang tidak tercemar Covid-19 sebelum memasuki wilayah Indonesia. Dalam Permenkumham RI Nomor 7 Tahun 2020 juga ditegaskan bahwa bagi pihak luar China diberikan izin untuk muncul kembali dalam keadaan terkendala agar masa legitimasi ITAP tidak lewat, sehingga pihak luar dapat kembali ke Indonesia setelah masa pandemi Covid-19. Untuk situasi ini, penjamin emisi dapat mengajukan permohonan penambahan hibah rumah bagi orang luar yang memegang izin tinggal terbatas atau hibah rumah jangka panjang di China kepada Kepala Kantor Imigrasi tanpa partisipasinya dengan mengikuti proposal atau peringatan dari posisi yang berwenang. 
Terungkapnya kasus Covid-19 di Indonesia pertama kali diumumkan oleh Presiden Joko Widodo pada 2 Maret 2020. Bagaimanapun, dua warga Indonesia asal Depok, Jawa Barat dinyatakan positif Covid-19. Dalam tahap mendasar ini, tampaknya otoritas publik masih sangat berhati-hati dalam melakukan pendekatan dan suka melakukan penghindaran gratis melalui pembersihan ramah, menjaga kerapian, dan membatasi perjalanan jika tidak terlalu mendesak.

Kementerian Luar Negeri Republik Indonesia pun telah memberikan imbauan, antara lain bahwa masyarakat akan lebih membatasi bepergian ke negara lain. Bagi mereka yang sekarang berada di luar negeri, mereka harus kembali ke Indonesia sebelum mengalami masalah penerbangan. Selain itu, otoritas publik juga melarang bagian untuk orang luar yang selama 14 hari terakhir mengunjungi Iran, Italia, Vatikan, Spanyol, Prancis, Jerman, Swiss, dan orang luar. berada di Indonesia dan tidak layak untuk kembali karena kurangnya sarana transportasi, maka hibah rumah terbatas diberikan. Mengenai orang luar Tiongkok yang memiliki izin tinggal terus-menerus yang masa legitimasinya untuk lisensi kemunculan kembali telah dihentikan, mereka dapat diberikan hibah kemunculan kembali dalam keadaan terbatas melalui permohonan kepada Petugas Imigrasi untuk jumlah korban positif Covid-19 di negara-negara ini.

Seiring bertambahnya jumlah korban Covid-19, Menkumham menolak RI No. 7 tahun 2020 dan memberikan Permenkumham RI No. 8 Tahun 2020 tentang Penghentian Sementara Visa Kunjungan dan Visa Kunjungan Gratis saat Kedatangan dan Pemberian Izin Tinggal bagi Perwakilan Republik Indonesia. Orang luar pemegang hibah rumah abadi bisa mendatangi petugas pergerakan di Kantor Perwakilan Republik Indonesia untuk meminta surat usulan masuk ke Indonesia. Status Dibatasi. Pendekatan tersebut ditetapkan pada 18 Maret 2020. Melalui pendekatan ini, otoritas publik secara singkat menghentikan pemberian Visa Kunjungan dan Visa Kunjungan Gratis bagi orang luar. Sementara itu, orang luar yang negaranya dipengaruhi oleh strategi lockdown diberikan Izin Tinggal Paksa, Izin Tinggal Terbatas, Izin Tinggal Tetap, Izin Re-section dan Tanda Masuk. Pengaturan ini dianggap tepat mengingat banyak negara telah melakukan lockdown, seperti yang berdampingan dengan Malaysia, yang melakukan lockdown pada 18 Maret 2020. Untuk terus memperluas upaya pencegahan Covid-19, otoritas publik mengingkari Menteri Negara Republik Indonesia. 
Meski demikian, di balik pengaturan yang dilakukan oleh otoritas publik, masih ada celah yang harus kita cermati bersama. Bagi sebagian besar orang luar yang berada di Indonesia dan memiliki penjamin emisi, mereka tidak akan merasa sulit untuk hidup. Beda halnya dengan, misalnya, tiga pemudik asal Rusia yang sempat beredar di internet sejak ketahuan mengamen di pasar Keboen Roek di Mataram, Nusa Tenggara Barat (NTB). Ketiganya datang ke Indonesia dengan memanfaatkan Visa Free Visit (BVK) melalui Bandara Sultan Syarif Kasim II Pekanbaru, Riau pada 16 Maret 2020. Kemudian mereka melanjutkan perjalanan ke Bali. Karena harga barang kebutuhan pokok di Bali biasanya tinggi, mereka pindah ke Lombok pada tujuh hari ketiga bulan April. Mereka yang tadinya ingin jalan - jalan di Lombok selama setengah bulan lalu melanjutkan perjalanan ke Jawa. Namun karena wabah Covid-19 yang mengakibatkan penutupan semua jalan sampai ke Bali dan Jawa, mereka memutuskan untuk tetap tinggal di Lombok. Untuk bertahan, mereka melakukan latihan mengamen di Covid-19. Saat dilakukan inspeksi bersama, pengaturan terkait pihak luar dilakukan secara bertahap oleh pasar. Atas keadaan tersebut, ketiga pihak luar di lingkungan Pemerintah tersebut tampaknya tidak memilih alternative pemegang BVK untuk diberikan opsi tinggal di Indonesia dengan dikeluarkannya Izin Tinggal Paksa (ITKT) sesuai Permenkumham RI No.11 tahun 2020 tentang Pelanggaran Sementara Orang Asing Masuk Wilayah Negara Republik Indonesia.

Karena ketiga orang luar Rusia itu ketahuan sedang mengamen saat mengawasi, hal itu menyinggung pasal 75 Undang-Undang Nomor 6 Tahun 2011 tentang Imigrasi, dimana latihan ketiga orang luar Rusia itu mengganggu permintaanpublik. Ketiga orang luar itu mendapat Tindakan Administratif Keimigrasian (TAK) sebagai ekstradisi seperti dikenang daftar keputusasaan. TAK bukanlah jenis pelanggaran common liberties yang diajukan oleh pihak migrasi Indonesia terhadap pihak luar, namun sebagai upaya pengerahan kapasitasnya sebagai pelaksana hukum di Indonesia. Adapun tujuan di balik orang luar untuk laporkan kepada agen negara yang bersangkutan di Indonesia untuk meminta bantuan.

Selama pandemi Covid-19, ini akan member gambaran bahwa tidak secara umum orang luar, terutama pemegang BVK, memiliki banyak uang. Sebagian besar dari mereka hanya memiliki uang biasa dan kemudian bepergian secara financial atau sering disebut sebagai pendaki. Ketika uang mereka habis sebelum pesanan mereka kembali, mereka berhasil bertahan seperti meminta, mengumpulkan aset, bermain musik, atau 
dalam hal apa pun. Melihat keajaiban ini, otoritas public harus waspada dan melakukan strategi tertentu untuk memilih orang luar yang masuk lebih ketat.

Pendekatan membatasi orang luar ke Indonesia yang dilakukan Pemerintah pada masa pandemi Covid-19 pada dasarnya merupakan upaya pemerintah untuk menjaga kesehatan warganya. Batasan ini adalah sistem yang sering digunakan oleh otoritas public suatu negara untuk membatasi hak istimewa individu tanpa dikatakan menyalahgunakan HAM. Keterbatasan orang luar ke Indonesia diidentifikasi dengan pilihan Organisasi Kesehatan Dunia (WHO) untuk membangun Covid sebagai pandemi.

\section{Pembatasan Pelayanan Paspor}

Setiap warga negara Indonesia yang ingin pergi keluar negeri wajib memiliki laporan kepindahan. Hal ini tertuang dalamUndang-Undang Republik Indonesia Nomor 6 Tahun 2011 yang berbunyi, "Setiap orang yang masuk atau keluar wilayah Indonesia wajib memiliki dokumen perjalanan yang sah dan masih berlaku." Laporan ini bisa sebagai identifikasi atau catatan perjalanan seperti visa. Pada dasarnya penerbitan pencatatan pergerakan merupakan salah satu upaya yang dilakukan oleh otoritas public untuk mengamankan penduduk selama berada di luar negeri.

Pengaturan langkah-langkah penerbitan laporan pergerakan merupakan salah satu jenis bantuan publik. Bantuan masyarakat itu sendiri sebagaimana diindikasikan oleh Undang-Undang Nomor 25 Tahun 2009 tentang Standar Pelayanan Publik merupakan gerakan atau pengaturan latihan untuk memenuhi kebutuhan administrasi sesuai dengan pedoman hukum bagi setiap penduduk dan penduduk untuk produk, administrasi publik. Untuk situasi ini, setelah seorang penduduk Indonesia menyelesaikan serangkaian siklus, ia memenuhi syarat untuk mendapatkan item dari badan regulasi sebagai catatan pergerakan. Administrasi publik di daerah migrasi pada dasarnya bersifat esensial karena semua penataan produk / administrasi public dilakukan oleh otoritas publik, untuk situasi ini otoritas public menjadi coordinator tunggal, sehingga klien / pelanggan harus memanfaatkannya.

Pertama - tama, pada pertengahan Maret 2020, para ahli migrasi sebenarnya belum menutup penyelenggara pergerakan, namun mereka sebenarnya mengikuti konvensi kesejahteraan yang ditetapkan oleh otoritas publik. Hal tersebut tertuang dalam Surat Edaran Nomor SEK-02.OT.02.02 Tahun 2020 tentang Pencegahan dan Penanganan Penyakit Virus Corona (Covid-19) di lingkungan Kementerian Hukum dan Hak Asasi 
Manusia. Surat edaran tersebut berisi himbauan kepada semua pekerja untuk melakukan upaya mencegah penyebaran Covid-19. Misalnya, menjamin aksesibilitas kantor, cuci tangan, pembersih tangan, menjaga kerapian iklim tempat kerja, membatasi perjalanan otoritas, memimpin pemeriksaan suhu, menjauhi kontak actual dengan kandidat, menggunakan penutup, dan terus menjelaskan kata dan kata Covid-19. Tidak menyebarkan berita penipuan yang diidentifikasi dengan Covid-19. Saat ini, keuntungan masyarakat dalam mengajukan pencatatan pergerakan masih cukup tinggi meskipun tujuannya juga bisa dianggap kurang berlaku untuk keadaan pandemi. Mayoritas dari mereka mengajukan surat perjalanan karena mereka memanfaatkan kuantitas jalur yang tidak terisi di APAPO.

Karena penyebaran Covid-19 yang sangat besar, otoritas public memberikan strategi selanjutnya untuk membatasi administrasi pergerakan. Pertama tama Batasan yang dipaksakan oleh otoritas public tertuang dalam ronde yang diberikan oleh Plt. Kepala Jenderal Imigrasi Nomor: IMI-GR.01.01-2114 Tahun 2020 tentang Pembatasan Pelayanan Keimigrasian untuk Mencegah Penularan Penyakit Virus Corona (Covid-19). Yang memuat bahwa administrasi hanya terbuka untuk calon dengan kebutuhan krisis, khususnya individu yang cacat disinggung klinik di luar negeri, Covid-19 mengurus petugas misi, kebutuhan untuk tetap konsentrasi di luar negeri, dan Tenaga Kerja Indonesia (TKI). TKI yang dimaksud bukanlah buruh yang barusaja diberangkatkan dari suatu negara pengaturan, melainkan seorang spesialis yang sedang cuti dan berada di Indonesia yang harus memperluas perjanjiannya dengan suatu organisasi atau atasan di luar negeri dengan tetap melegitimasi identitasnya akan segera berakhir. Kedua, penonaktifan sementara Aplikasi Pendaftaran Antrian Paspor Online (APAPO). Aplikasi APAPO adalah aplikasi visa line berbasis online yang berisi data tentang kebutuhan aplikasi, informasi calon individu, dan rencana penampilan. Selain itu, masyarakat umum juga bisa mengaksesnya melalui web https://antrian.imigration.go.id/.

Penonaktifan APAPO adalah kunci penting karena pendaftaran untuk aplikasi visa harus dilakukan melalui aplikasi ini. Ketiga, akhir dari ukuran bermacam-macam identifikasi. Menyinggung Permenkumham RI No. 8/2014 tentang Paspor Biasa dan Paspor Perjalanan, . Kandidat identifikasi dapat mengumpulkan visa setelah kerangka waktu pandemi ditutup. Keempat, tidak ada denda bagi pemegang visa yang terlambat melakukan pergantian identitas dengan alasan telah lewat masa legitimasi. Harus diakui bahwa selama wabah Covid-19, otoritas public tidak bisa menjaga seperti yang 
ditunjukkan oleh Satrio yang mengutip Irfan Islamy (1999) bahwa setiap jenis pemerintahan harus nonstop.

Menawarkan jenis bantuan bagi calon yang dianggap memiliki kebutuhan krisis merupakan salah satu upaya otoritas public memberikan gerakan administrasi yang paling ekstrim selama pandemi Covid-19. Pemerintahan daerah setempat mewajibkan setiap komponen dalam organisasi memiliki kepedulian terhadap daerah setempat tanpa mengabaikan HAM.

\section{Kendala yang dihadapi dalam Proses Pelaksanaan Keimigrasian pada Masa Pandemi Covid-19}

Untuk mencegah penyebaran infeksi Covid-19, otoritas public telah memberikan beberapa pengaturan seperti yang digambarkan sebelumnya. Namun, selama waktu yang dihabiskan untuk melaksanakan pengaturan, masih banyak halangan di lapangan. Pertama-tama, ini diidentifikasikan dengan cara untuk membatasi orang luar agar tidak masuk ke Indonesia. Menjelang dimulainya episode infeksi Covid-19, petugasmigrasi, terutama yang berada di TPI atau PLB, sering menghadapi hambatan karena tidak adanya perangkat klinis seperti penutup, sarung tangan, dan pembersih tangan. Sejujurnya ini adalah dampak dari hiruk pikuk pembelian yang dilakukan oleh daerah setempat dan berefek pada kekurangan gadget klinis tersebut. Padahal seharusnya petugas pergerakan membutuhkan gadget klinis karena mereka cepat bertemu dengan orang luar saat masuk ke Indonesia.

Banyaknya orang luar yang tidak bisa kembali ke negara asalnya karena pelaksanaan lockdown dan tidak ada metode transportasi bagi mereka untuk kembali, telah membuat banyak orang luar di Bali mengantri ke Kantor Imigrasi untuk mengajukan perluasan krisis mereka. Tinggal hibah. Bahkan antrean pun tercurah hingga kedepan Kantor Imigrasi. Pada 23 Maret 2020, Kantor Wilayah Kementerian Hukum dan Hak Asasi Manusia di Bali memperhatikan bahwa 1.830 orang luar telah mengajukan izin tinggal krisis. Gerombolan orang luar yang mengunjungi Kantor Imigrasi ternyata sangat memprihatinkan, karena selama periode Covid-19, orang harus menjauh dan tetap menerapkan aturan kesehatan.

Kedua, penghalang yang dihadapi diidentifikasi dengan strategi pembatasan administrasi identifikasi. Dengan adanya pendekatan ini, maka pengaruh yang 
dirasakan otoritas public adalah berkurangnya ukuran Penerimaan Negara Bukan Pajak (PNBP) dari permohonan identifikasi. 


\section{KESIMPULAN}

Mengingat pembahasan di atas, sangat mungkin bahwa infeksi Covid-19 berisiko bagi individu di Indonesia. Transmisi cepat sampai pada titik bahwa otoritas public telah memberikan setidaknya dua pengaturan migrasi sebagai jalan bagi negara untuk menekannya. Kedua pendekatan tersebut adalah pembatasan orang luar ke domain Indonesia dan pembatasan administrasi visa, namun ditemukan beberapa hambatan. Misalnya, tidakadanya peralatan klinis untuk petugas migrasi, perkembangan gejolak bagi orang luar yang tidak bisa kembali kenegaranya sehingga mereka mengerumuni Kantor Imigrasi untuk memperluas hibah rumah mereka, ukuran biaya hidup yang tidak signifikan bagi orang luar di Indonesia dengan Tujuannya agar mereka bisa mengajukan pelanggaran perpindahan, dan berkurangny agaji PNBP karena pengurangan jumlah calon visa. 


\section{DAFTARPUSTAKA}

\section{Buku}

Nowak,Manfred.Introductionto the International HumanRightsRegime. Leiden:Brill, 2004.

\section{Jurnal/Makalah/Prosiding}

Shofia, TrianingIndarti.2020,"Immigration Policy During Covid-19: Human Rights

Perspective"

Masykuri Abdillah: Islam dan Hak AsasiManusia

M. ARIEF HAMD,"PENGIDENTIFIKASIAN DAN TINDAKAN HUKUM BAGI ORANG ASINGYANG TIDAK MEMEGANG PASPOR DI WILAYAH INDONESIA"

\section{PeraturanPerundang-Undangan}

“Undang-Undang No.6 Tahun2011Tentang Keimigrasian,"2011.

“Undang-Undang RI No.39Tahun 1999

Tentang Hak Asasi Manusia,"1999.“Universal Declaration of Human Rights,"1948.

\section{SumberLain}

Tim Gugus Tugas Percepatan Penanganan COVID-19. "DataSebaranCovid-19Di Indonesia." Https://Covid19.Go.Id/.

Lastmodified2020.AccessedMay11,2020.https://covid19.go.id/

HumasKemkes RI.“SituasiTerkiniPerkembangan Coronavirus Disease (COVID-19) 19Maret2020." KemkesRI.

Lastmodified2020.AccessedMarch20,2020.https://covid19.kemkes.go.id/situasi-in feksi-emerging/info-corona-virus/situasi-terkini-perkembangan-coronavirus-diseas e-covid-19-19-maret-2020/\#.Xz3JrPMzblU. 